\title{
Pengembangan Model Pengambilan Keputusan Multi Kriteria dalam menentukan Trade-Off Tujuan Berkonflik menggunakan Global Criterion Method
}

\author{
Sutrisno $^{1}$, Dyah Rachmawati Lucitasari ${ }^{1}$ \\ ${ }^{1}$ Jurusan Teknik Industri, Fakultas Teknik Industri, \\ Universitas Pembangunan Nasional Veteran Yogyakarta \\ Jl. Babarsari 2 Tambakbayan, Yogyakarta 55281 \\ Telp (0274)485268, Fax (0274)486256 \\ email : trisno_upnvy@yahoo.co.id \\ doi: https://doi.org/10.31315/opsi.v12i2.3165
}

Received: $16^{\text {th }}$ October 2019; Revised: $28^{\text {th }}$ November 2019; Accepted: $30^{\text {th }}$ December 2019; Available online: $31^{\text {st }}$ December 2019; Published regularly: December 2019

\begin{abstract}
Decision making by company management is mostly multi-criteria decision making. Multi-criteria corporate decision making is characterized by having to make decisions on several corporate objectives that are mutually contradictory. Service companies generally want to maximize customer satisfaction and minimize company operating costs. Customer satisfaction can be maximized, by implementing programs that are expected to maximize the level of customer satisfaction. Implementation of these programs will increase the company's operational costs, which in turn can reduce company profits. The company's goal to increase customer satisfaction results in increased operational costs, so that it is contradictory to the second corporate goal of minimizing company operating costs, which is a multi-criteria decision making problem.

Trade-offs are sought from two contradictory service company objectives, namely maximizing customer satisfaction and minimizing company operating costs, firstly, a multi-criteria decision making model will be developed. The decision-making model developed is a mathematical model consisting of two contradictory objective function functions, namely the maximization of the level of customer satisfaction and the minimization of the company's operating costs, as well as a limitation which is a mathematical translation of the things that limit the achievement of these two company goals. After a mathematical model of multi-criteria decision making is formed, the next step is to look for trade-offs from the two company's goals using the global criterion method.
\end{abstract}

Keywords: making multi-criteria decisions; trade-offs; global criterion methods

\begin{abstract}
ABSTRAK
Pengambilan keputusan yang dilakukan manajemen perusahaan kebanyakan adalah pengambilan keputusan bersifat multi kriteria. Pengambilan keputusan perusahaan bersifat multi kriteria ditandai dengan harus dilakukannya pengambilan keputusan atas beberapa tujuan perusahaan yang saling bersifat kontradiktif. Perusahaan jasa umumnya ingin memaksimalkan kepuasan pelanggannya dan meminimalkan biaya operasional perusahaan. Kepuasan pelanggan dapat dimaksimalkan, dengan melaksanakan program-program yang diharapkan dapat memaksimalkan tingkat kepuasan pelanggan. Pelaksanaan program-program tersebut akan menaikkan biaya operasional perusahaan, dimana pada akhirnya dapat menurunkan keuntungan perusahaan. Tujuan perusahaan untuk meningkatkan kepuasan pelanggan berakibat dengan naiknya biaya operasional, sehingga kontradiktif dengan tujuan perusahaan yang kedua yaitu meminimalkan biaya operasional perusahaan, yang merupakan permasalahan pengambilan keputusan multi kriteria.

Trade-off dicari dari dua tujuan perusahaan jasa yang saling kontradiktif, yaitu memaksimalkan kepuasan pelanggan dan meminimalkan biaya operasional perusahaan, pertama akan dikembangkan model pengambilan keputusan multi kriteria. Model pengambilan keputusan yang dikembangkan adalah model matematis terdiri dari dua fungsi tujuan saling kontradiktif, yaitu maksimasi tingkat kepuasan pelanggan dan minimasi biaya operasional perusahaan, serta pembatas yang merupakan penjabaran matematis dari hal yang membatasi tercapainya dua tujuan perusahaan tersebut. Setelah model matematis pengambilan keputusan multi kriteria terbentuk, langkah selanjutnya adalah mencari trade-off dari dua tujuan perusahaan tersebut menggunakan global criterion method.
\end{abstract}

Kata Kunci: pengambilan keputusan multi kriteria; trade-off; global criterion method 


\section{PENDAHULUAN}

Pengambilan keputusan dalam suatu perusahaan merupakan suatu tindakan yang harus diambil oleh manajemen perusahaan dalam menentukan kebijakan-kebijakan strategis perusahaan, seperti optimalisasi tingkat kepuasan pelanggan untuk menjaga loyalitas pelanggan, minimasi biaya produksi untuk mengoptimalkan efisiensi perusahaan, dan lain sebaginya. Pengambilan keputusan dalam suatu perusahaan harus dilakukan secara optimal. Optimalitas pengambilan keputusan yang dilakukan oleh manajemen perusahaan dapat diukur dari tingkat pencapaian tujuan yang telah ditetapkan oleh perusahaan.

Suatu perusahaan, apapun jenisnya, baik perusahaan manufaktur, perusahaan proses, ataupun perusahaan jasa pasti mempunyai banyak tujuan atau kebijakan yang harus dicapai. Tujuan-tujuan perusahaan tersebut kadang kala satu sama lain saling berkonflik atau kontradiktif. Konflik antara satu tujuan dengan tujuan yang lainnya diindikasikan dengan turunnya pencapaian suatu tujuan disaat tujuan yang lainnya dinaikkan ketercapaiannya. Langkah-langkah optimasi perlu dilakukan agar tujuan-tujuan perusahaan yang saling berkonflik dapat dioptimalkan ketercapaiannya dengan baik. Optimasi terhadap tujuan-tujuan yang saling berkonflik merupakan permasalahan dalam pengambilan keputusan multi kriteria. Untuk mempermudah manajemen perusahaan dalam melakukan pengambilan keputusan terhadap tujuan perusahaan yang saling berkonflik maka perlu dikembangkan model pengambilan keputusan multi criteria.

Pada penelitian ini akan dikembangkan suatu model pengambilan keputusan multi criteria untuk melakukan optimasi terhadap dua tujuan yang saling berkonflik pada perusahaan jasa, yaitu maksimasi tingkat kepuasan pelanggan dan minimasi biaya operasional yang ditimbulkan, dengan pembatas berupa keterbatasan sumber daya perusahaan untuk mencapai tujuan-tujuan tersebut. Eksistensi perusahaan jasa sangat bergantung kepada tingkat kepuasan pelanggan dalam merasakan jasa yang telah diterimanya. Semakin tinggi tingkat kepuasan pelanggan terhadap jasa yang diterimanya maka semakin eksis perusahaan tersebut, karena akan mendapatkan pelanggan yang semakin banyak, sehingga maksimasi tingkat kepuasan pelanggan merupakan tujuan utama dari suatu perusahaan jasa. Untuk memaksimalkan tingkat kepuasan pelanggan, pasti diperlukan biaya operasional untuk melaksanakan program-program yang dapat memaksimalkan tingkat kepuasan pelanggan tersebut, sehingga perlu diupayakan untuk memaksimalkan tingkat kepuasan pelanggan dengan menggunakan biaya operasional sekecil mungkin. Tujuan kedua dari suatu perusahaan jasa adalah minimasi biaya operasional perusahaan, yang merupakan upaya perusahaan jasa untuk meminimalkan biaya operasional sebagai upaya untuk menekan pengeluaran perusahaan yang salah satunya digunakan memaksimalkan kepuasan pelanggan tersebut. Model optimasi ini akan menjembatani manajemen perusahaan jasa untuk memaksimalkan tingkat kepuasan pelanggan sehingga akan menghasilkan semakin banyak pelanggan yang loyal terhadap perusahaan, tetapi biaya operasional untuk memaksimalkan tingkat kepuasan pelanggan tersebut dapat ditekan sekecil mungkin.

Optimasi model dengan pengambilan keputusan multi criteria yang dikembangkan, akan dilakukan menggunakan global criterion method. Kelebihan dari metode ini adalah akan didapatkan nilai setiap fungsi tujuan yang mempunyai deviasi minimal terhadap nilai idealnya. Hal ini dikarenakan dengan metode ini akan dilakukan minimasi terhadap global objective function dari jumlah deviasi nilai fungsi tujuan individual terhadap nilai idealnya, yang diwujudkan sebagai rasio terhadap nilainilai ideal tersebut.

Optimasi pada model pengambilan keputusan multi criteria yang dilakukan akan menghasilkan tingkat kepuasan pelanggan yang maksimal dengan biaya operasional perusahaan yang minimal. Hasil optimasi tersebut diharapkan dapat meningkatkan daya saing perusahaan jasa dalam persaingan di era global. Peningkatan daya saing perusahaan jasa dengan memaksimalkan tingkat kepuasan pelanggan dan sekaligus melakukan efisiensi dengan meminimalkan biaya operasional, akan menjadi modal penting bagi perusahaan jasa dalam negeri pada saat bersaing dengan perusahaan jasa dari luar negeri yang sudah banyak beroperasi di Indonesia, seperti perusahaan asuransi asing dan perusahaan jasa pengiriman barang asing..

Berdasarkan uraian dalam latar belakang masalah di atas maka masalah yang diangkat pada penelitian ini adalah bagaimana mengembangkan model pengambilan keputusan 
multi kriteria pada perusahaan jasa untuk menentukan trade-off dari dua tujuan perusahaan yang saling berkonflik menggunakan global criterion method.

Batasan masalah dalam penelitian ini adalah: (1)Model pengambilan keputusan multi kriteria yang dikembangkan adalah model optimasi dari dua tujuan perusahaan jasa yang saling berkonflik dengan batasan berupa keterbatasan sumberdaya perusahaan dalam mencapai dua tujuan tersebut. (2)Tujuan perusahaan yang akan ditentukan nilai trade off nya dalam penelitian ini adalah maksimasi tingkat kepuasan pelanggan dan minimasi biaya operasional perusahaan.

Tujuan yang akan dicapai pada penelitian ini adalah mengembangkan model pengambilan keputusan multi kriteria pada perusahaan jasa untuk menentukan trade off dari dua tujuan perusahaan yang saling berkonflik menggunakan global criterion method.

\section{METODE}

Objek dalam penelitian ini adalah perusahaan jasa, yang akan mengembangkan model pengambilan keputusan multi kriteria untuk menentukan trade off dari dua tujuan perusahaan saling berkonflik. Optimasi atau penentuan nilai trade off dari dua tujuan perusahaan yang saling berkonflik akan dilakukan menggunakan global criterion method. Teknik pengumpulan data yang digunakan dalam penelitian ini terdiri dari dua jenis data, data primer diperoleh dengan wawancara terhadap pimpinan perusahaan jasa, data kuesioner yang diberikan kepada pimpinan dan karyawan perusahaan jasa yang ada di Yogyakarta. Data sekunder diperoleh dari data operasional perusahaan jasa yang ada di Yogyakarta. Pengembangan Model dalam penelitian ini: (a). Pengumpulan Data, perusahaan jasa yang menjadi objek dari penelitian ini adalah perusahaan jasa pengiriman barang CV. Interindo. Data-data yang diperlukan untuk mengembangkan model pengambilan keputusan multi kriteria pada perusahaan jasa ini adalah data jumlah tenaga kerja, data jumlah pekerjaan, data jumlah jam kerja, data lama waktu pengiriman, data ongkos pengiriman barang, dan data tingkat kepuasan pelanggan. (b). Pengolahan Data, data-data yang sudah dikumpulkan akan dilakukan pengolahan data untuk menentukan parameter - parameter, konstanta, dan variabel keputusan dari model matematika yang dikembangkan. Selanjutnya dapat dikembangkan model matematika yang terdiri dari dua fungsi tujuan yang saling berkonflik dan pembatas untuk tercapainya dua tujuan perusahaan tersebut. (c) Pengembangan Sistem Pengambilan Keputusan Multi Kriteria, sistem pengambilan keputusan multi kriteria yang dikembangkan berupa model matematika yang terdiri dari dua tujuan perusahaan yang saling berkonflik, dan pembatas pencapaian dua tujuan tersebut.

Tahapan pengembangan nodel matematika dalam persoalan ini adalah: (1) Menentukan variable keputusan, variabel keputusan disini adalah berat empat barang yang paling sering dikirim oleh $\mathrm{CV}$. Interindo dalam setiap harinya. Variabel keputusan tersebut adalah: $\mathrm{x}_{1}$ :berat paket jenis 1 yang dikirim per hari (puluh $\mathrm{kg}$ ); $\mathrm{x}_{2}$ : berat paket jenis 2 yang dikirim per hari (puluh $\mathrm{kg}$ ); $\mathrm{x}_{3}$ : berat paket jenis 3 yang dikirim per hari (puluh $\mathrm{kg}$ ); $\mathrm{x}_{4}$ : berat paket jenis 4 yang dikirim per hari (puluh $\mathrm{kg}$ ). (2) Menentukan fungsi tujuan, dalam menentukan fungsi tujuan perlu ditentukan parameter-parameter fungsi tujuan terlebih dahulu. Fungsi tujuan dari model matematika pengambilan keputusan multi criteria ini adalah maksimasi kepuasan pelanggan $\left(Z_{l}\right)$ dan minimasi biaya operasional perusahaan $\left(Z_{2}\right)$. Formulasi fungsi tujuannya adalah sebagai berikut:

Maksimasi $Z_{1}=f_{l}(X)=0,17 x_{1}+0,25 x_{2}+0,45$ $x_{3}+0,57 x_{4}$

Minimasi $Z_{2}=f_{l}(X)=115000 x_{1}+123000 x_{2}+$ $163000 x_{3}+154000 x_{4}$

(3) Menentukan fungsi pembatas, (a) batasan berat barang yang dikirim dalam satu kali pengiriman, batasan ini mempunyai formulasi matematika sebagai berikut:

$X_{1}+X_{2}+2 X_{3}+X_{4} \leq 2000$

(b) batasan jumlah jam kerja, batasan waktu set up setiap barang dan jumlah jam kerja yang tersedia mempunyai formulasi matematika sebagai berikut:

$24 X, 45_{1}+15,34 X_{2}+21,84 X_{3}+17,56 X_{4} \leq 945$ 
(c) batasan ketersediaan jumlah tenaga kerja, Formulasi matematika untuk alokasi tenaga kerja pada setiap barang dan jumlah tenaga kerja yang tersedia adalah sebagai berikut:

$X_{1}+3 X_{2}+4 X_{3}+2 X_{4} \leq 25$

(d) batasan non negative, suatu batasan yang menyatakan bahwa berat barang yang dikirim tidak mungkin negative, batasan non negative adalah: $\mathrm{X}_{1}, \mathrm{X}_{2}, \mathrm{X}_{3}, \mathrm{X}_{4} \geq 0$

(4) Menentukan trade-off dari model matematika yang dibangun menggunakan global criterion method. Langkah-langkah penyelesaiannya adalah sebagai berikut: 4 . Menentukan trade-off dari model matematika yang dibangun menggunakan global criterion method. Langkah-langkah penyelesaiannya adalah sebagai berikut: (a)Tentukan solusi ideal masing-masing fungsi tujuan, solusi ideal masing-masing fungsi tujuan dicari dengan metode simpleks menggunakan software win $Q S B$. Solusi ideal masing-masing fungsi tujuan adalah: $Z_{1} *=Z_{1}$ maksimal $=7,5$ dengan $x_{1} *=\left(0,30,0,0 ; \quad Z_{2} *=Z 2 \quad\right.$ minimal $=2300000$ dengan $x_{2} *=(20,0,0,0)(b)$. Model matematika dari persoalan multi criteria yang diselesaikan menggunakan global criterion method adalah:

Minimasi

$Z=((7,5-(0,17 \times 1+0,25 \times 2+0,45 \times 3+0,57 \times 4)) / 7,5)$

$+((2300000-(115000 \times 1+123000 \times 2+163000 \times 3$

$+154000 \times 4)) / 2300000)$

Pembatas

$X_{1}+X_{2}+2 X_{3}+X_{4} \leq 2000$

$24 X, 45_{1}+15,34 X_{2}+21,84 X_{3}+17,56 X_{4} \leq 945$

$X_{1}+3 X_{2}+4 X_{3}+2 X_{4} \leq 25$

$X_{1}+3 X_{2}+4 X_{3}+2 X_{4} \leq 25$

$\mathrm{X}_{1}, \mathrm{X}_{2}, \mathrm{X}_{3}, \mathrm{X}_{4} \geq 0$

\section{HASIL DAN PEMBAHASAN}

Solusi dari model matematika diatas adalah: $x^{*}=(0,26,4,0)$, sehingga nilai trade-off yang didapat adalah : $Z_{1}=6,8$ dan $Z_{2}=3112000$. Nilai trade-off dari persoalan pengambilan keputusan multi kriteri dengan penyelesaian menggunakan global criterion method adalah $\mathrm{Z}_{1}$ $=6,8$ dan $Z_{2}=3112000$. Jadi disini nilai $Z_{1}=6,8$ jika dibandingkan dengan nilai idealnya, yaitu 7,5 , maka terjadi deviasi sebesar 0,7 . Sedangkan nilai $Z_{2}=3112000$, jika dibandingkan dengan nilai idealnya yaitu 2300000 , maka terjadi deviasi sebesar 812000. Jadi secara logika penyelesaian tersebut sudah benar, karena (a) untuk maksimasi $Z_{1}$ didapatkan nilai trade-off untuk $Z_{1}=6,8$ yang lebih kecil dari nilai idealnya, yaitu 7,5. (b) Untuk minimasi $Z_{2}$ didapatkan nilai trade-off untuk $Z_{2}=3112000$ yang lebih besar dari nilai idealnya, yaitu 2300000 .

\section{KESIMPULAN}

Sistem pengambilan keputusan multi kriteria menggunakan global criterion method telah memberi banyak salah satu opsi kepada pengambil keputusan dalam melakukan optimasi

\section{DAFTAR PUSTAKA}

Balteiro, L.D., Pachon, J.G., Romero, C., (2017), Measuring Systems Sustainability with Multi-Criteria Methods: A Critical

Review, European Journal of Operational Research, Elesevier, Vol 258, Issue 2, Pages 607-616.

Belton, Stewart, (2005), Gamete and Immune Cell Recognition Revisited, BioEssay, Volume 7, Issue 12

Cinelli, M., Coles, S. R., Kirman, K., (2014), Analysis of ThePotentials of MultiCriteria Decision Analysis Methods to Conduct Sustainability Assessment, Ecological Indicators, Elsevier, Volume 46, Pages 138-148

Pohekar, S. D., Ramachandran, M., (2004), Application of Multi-Criteria Decision Making to Sustainable Energy Planning-A Review, Renewable and Sustainable Energy Reviews, Elsevier, Volume 8, Issue 4, Pages 365-381

Gungor, (1999), Issues in Environmentally Conscious Manufacturing and Product Recovery: a survey, Computer \& Industrial Engineering, Elsevier, Volume 36 , issue $4,811-853$

Handayani, T., Wakhidah, N., (2012), Penerapan SPK Untuk Seleksi Mahasiswa Berprestasi Menggunakan Metode AHP, Jurnal Universitas Semarang, Volume 1 Nomor 2.

Huang, I.B., Keisler. J., Linkov, I., (2011), Multi-Criteria Decision Analysis in Environmental Science : Ten Years of Applications and Trends, Science of The Total Environment, Elsevier, Volume 409, Issues 19, Pages 3578 - 3594

Indrianti, N., Sutrisno, (2014), Buku Ajar Pengambilan Keputusan Multi Kriteria, UPN "Veteran" Yogyakarta, Yogyakarta

Jiang, W.Y., Chun, Y.J., Jun, F.Z., Zhao, H., (2009), Review on Multi-Criteria Decision Analysis Aid in Sustainable Energy Decision-making, Renewable and 
Sustainable Energy Reviews, Elsevier, Vol 13, Issue 9, Pages 2263 - 2278

Kleindorfer, (2005), Sustainable Operations Management, Production and Operations Management, Volume 14, Issue 4, 482492

Muhsin, A. (2014), Logika Pemrograman dan Dasar Komputer, Jurusan Teknik Industri UPN "Veteran" Yogyakarta, Yogyakarta.

Rahardjo, J., Stok, R., Yustina, R.,(2000), Penerapan Multi-Criteria Decision Making Dalam Pengambilan Keputusan Sistem Perawatan, Jurnal Teknik Industri, Volume 2, Nomor 1, Halaman 1-12
Ristono, A., (2011), Pemodelan Sistem, Graha Ilmu, Yogyakarta

Rohayani, H., (2013), Analisis Sistem Pendukung Keputusan Dalam Memilih Program Studi MenggunakanMetodeLogika Fuzzy, Sriwijaya Journal of Information Systems Si, J., Halburd, L.M., Nasiri, F., Bell, S., (2016), Assessment of Building-integrated Green Technologies: A Review and Case Study on Applications of Multi-Criteria Decision Making (MCDM) Method, Sustainable Cities and Society, Elsevier, Vol 27, Pages $106-115$ 